\title{
The Design of Performance Measurement of Tadulako University Using Balanced Scorecard Approach
}

\author{
Rahmahhayati Paturusi ${ }^{1} \nless$ \\ Ujang Sumarwan ${ }^{2}$ \\ Sahara $^{3}$
}

'School of Business, Bogor Agricultural University (IPB), Pajajaran Street, Bogor 16151, Indonesia Email:rahmahhavati19ek@mma.ipb.ac.id Tel:62-251-831-3813

School of Business IPB, Pajajaran Street, Bogor 16151, Indonesia

${ }^{2}$ Email:usumarwan@apps.ipb.ac.id Tel:62-251-831-3813

${ }^{s}$ Email:sahara_ipb@yahoo.com Tel:62-251-831-3813

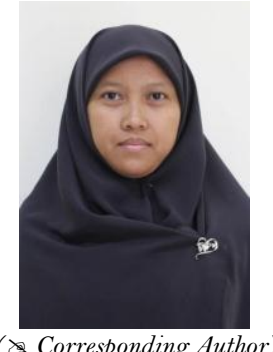

\begin{abstract}
The purpose of this research is to develop Balanced Scorecard (BSC) for UNTAD. BSC is a performance measurement tool organization which is a strategic management system of the organization. BSC is used to articulate the mission, vision, goals and strategies into some comprehensive, coherent and measurable strategic objectives and strategic initiatives. BSC aims to improve organizational performance. This research uses descriptive technique through case study and focuses on observing the form of performance measurement used by UNTAD. This research employs purposive sampling method. The amount of strategic objectives arranged using BSC was 17 with 75 Key Performance Indicators (KPIs). Prioritization of strategic objectives is accomplished by using Analytic Network Process (ANP). The results of this study indicate that customer perspective is the first priority, followed by learning and growth perspective, internal business process perspective, and financial perspective. BSC development should be planned by the university planning department, implemented by all units, and evaluated by internal supervision unit.
\end{abstract}

Keywords: Analytic network process (ANP), Balanced scorecard (BSC), Higher education.

Citation | Rahmahhayati Paturusi; Ujang Sumarwan; Sahara (2018). The Design of Performance Measurement of Tadulako University Using Batanced Scorecard Approach Asion Jourt c Using History:

Received: 9 February 2018

Revised: 26 March 2018

Accepted: 28 March 2018

Published: 30 March 2018

Licensed: This work is licensed under a Creative Commons Attribution 3.0 License (cc) E E

Publisher: Asian Online Journal Publishing Group
Contribution/Acknowledgement: Authors would like to convey sincere gratitude to the leaders of Tadulako University (UNTAD) which were willing to be respondents of this research and help the authors in data collection process.

Funding: This study received no specific financial support

Competing Interests: The authors declare that they have no conflict of interests.

Transparency: The authors confirm that the manuscript is an honest, accurate, and transparent account of the study was reported; that no vital features of the study have been omitted; and that any discrepancies from the study as planned have been explained.

Ethical: This study follows all ethical practices during writing.

\section{Contents}

1. Introduction

2. Literature Review

3. Methods

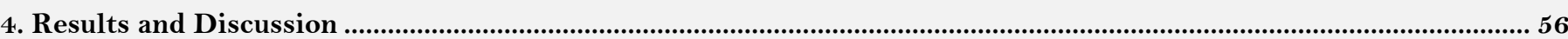

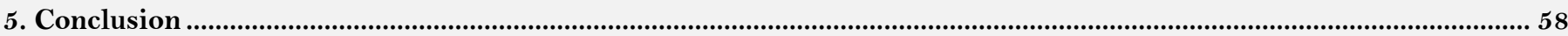

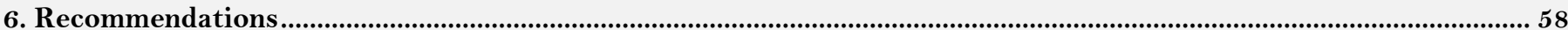

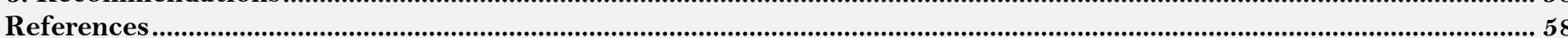

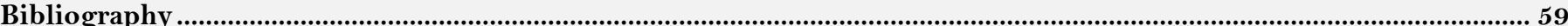




\section{Introduction}

The success of an organization can be seen from its performance. The performance will show the achievements obtained. Every organization wants to know how its performance is. In addition to determining the upcoming year's strategy, performance is also used as a form of accountability to stakeholders. The importance of knowing the achievements encourages the performance measurement (Fitriyani, 2014). Performance measurement is a process of performance evaluation conducted by standard setting, performance assessment in the form of comparing performance based on established standards and feedback whether by giving suggestion or inputs, and training for performance improvement, as well as reward as a form of appreciation for good performance (Dessler, 2006). Organization can improve performance by making the performance measurement results as a benchmark for strategy formulation. Implementation of the strategy can be successfully implemented if the organization is able to translate strategy into performance measurement system (Wibisono et al., 2011).

Performance measurement is one of the important factors in an organization because it can assess the success of organization. A good performance measurement will not only assess the success of organization, but also can be used as a reference in determining targetof the next period. For example, the use of the Balanced Scorecard (BSC) in performance measurement. BSC is a performance measurement tool that was introduced by Kaplan and Norton (1996) with the aim of improving performance of an organization that was originally only used by business organization. BSC utilization in various organizations allow a more extensive and comprehensive utilization. Niven (2008) even developed a BSC which is suitable for use by government agencies and nonprofit organizations.

$\mathrm{BSC}$, in performance measurement, can provide a more structured and comprehensive picture, compared to traditional systems which are still widely used today (Rumintjap, 2013). Using the BSC in performance reporting allows universities to focus on strategic educational services and become its excellence, adjust with the annual activity plan, and provide information for the improvement required by higher education (Tohidi et al., 2010). BSC can also help in translating vision and mission into objectives, benchmarks, targets, and strategic initiatives (Hermawan, 2008).

Public tertiary educational institutions (PTN) are center for implementing Tridharma and they own discretion to manage it. Tertiary educational institution's autonomy should be given selectively based on PTN performance evaluation (Law Number, 2012). As a consequence of this autonomy, tertiary educational institutions are required to carry out the implementation efficiently, improve the quality, and conduct a performance measurement (Fontanella and Andriani, 2009). Performance measurement is conducted to identify the actual condition experienced by the organization. Comprehensive information is needed by the organization to achieve results that truly reflect the real condition so that it can be used for the improvement of organization as well as the determination of next period's strategic objectives.

Tertiary educational institution, as an organization, wants to produce quality outputs. Graduates, researches, and community service activities are expected to contribute to Indonesia. Education is one of the nation's capital to grow and prosper. National development vision is that in 2025 Indonesia could be independent, developed, fair and prosperous if it can advance the intellectual life of its people by advancing the science and technology to promote civilization and mankind welfare.

The government, in this case is the Ministry of Research, Technology, and Higher Education, organizes a Quality Assurance System of Higher Education in order to ensure that quality higher education is well conducted.Quality Assurance System of Higher Education consists of Internal and External Quality Assurance System. Internal quality assurance is carried out by the tertiary educational institution istelf with the terms and ways determined by the government.Meanwhile, external quality assurance is undertaken by the National Accreditation Board for Higher Education (BAN-PT) by issuing the accreditation score of the study program and the tertiary educational institution. A well conducted internal quality assurance will help the tertiary educational institution in obtaining a good external quality assurance as well. Accreditation score issued by BAN-PT becomes the main indicator used by the public to assess the tertiary educational institution. A good accreditation score achieved by a tertiary educational institution or study program becomes a major representation that the institution has a good management and will produce good quality graduates. Therefore, it becomes important for every tertiary educational institution to have a good accreditation score from BAN-PT, including for Tadulako University (UNTAD).

UNTAD is one of the public tertiary educational institutions in the eastern Indonesia. Based on the rating conducted by Ministry of Research, Technology, and Higher Education on 3320 tertiary educational institutions in 2015, UNTAD is ranked 35 and the accredited B by BAN-PT (2016). Although it becomes a pride but of all the 56 study programs (prodi) UNTAD has, there is only two prodiwhich are accredited A. Increasing the number of prodi with A accreditation score is one of the main problems encountered by UNTAD. It is important for UNTAD to determine a performance measurement which is comprehensive and in accordance with UNTAD's current condition, so that it will improve UNTAD's performance and outputs quality. The purpose of this study is to develop a UNTAD's BSC which will serve as a tool for performance measurement and strategy management.

\section{Literature Review}

Research regarding BSC has been widely conducted, both in the development of BSC concept and its application in companies, government agencies, and tertiary educational institutions. BSC is increasingly used by organizations. Research on the importance of using BSC argued that by using BSC in performance measurement, an organization can obtain a more structured and comprehensive picture, compared to using traditional systems (Rumintjap, 2013) the organization will focus on strategic educational services, the annual action plan can be harmonized, and the personnel engagement in decision-making will increase (Tohidi et al., 2010).

Great benefits expected from the use of BSC cause the large number of researches on the design of performance measurement based on BSC. Performance measurement using BSC is one of researches conducted in tertiary educational institutions. This research is based on the theory that BSC as a performance management system can be used in improving the accountability of tertiary educational institutions because it can help them in translating vision, mission, and strategy into a series of performance indicators (Sudirman, 2012). Obstacles in strategy 
implementation can be minimized by a balanced strategy mapping in BSC. The use of BSC in tertiary educational institution requires some adjustments so that they will reduce the failure risk in implementation process and can improve organizational performance (Aljardali et al., 2012).

\subsection{Customer Perspective}

Performance indicators used by some researchers on customer perspective are improving service quality (Wu et al., 2011; Nur, 2013; Quezada et al., 2014; Fooladvand et al., 2015) value of customer satisfaction (Hermawan, 2008; Sukesti, 2010; Tohidi et al., 2010; Wu et al., 2011; Aljardali et al., 2012; Effendi, 2012; Suhendi, 2012; Atafar et al., 2013; Rumintjap, 2013; Santhi et al., 2013; Angriani, 2014; Antariksa et al., 2014; Quezada et al., 2014; Fooladvand et al., 2015; Sudaryo, 2015) consistent with customer expectation (Atafar et al., 2013) and timely delivery (Fooladvand et al., 2015)improvement of relationship with alumni and users (Wu et al., 2011; Suhendi, 2012) customer retention (Sukesti, 2010; Wu et al., 2011; Effendi, 2012; Rumintjap, 2013; Angriani, 2014; Quezada et al., 2014) customer acquisition (Hermawan, 2008; Sukesti, 2010; Wu et al., 2011; Effendi, 2012; Suhendi, 2012; Rumintjap, 2013) market share (Wu et al., 2011; Effendi, 2012) amount of awards achieved (Suhendi, 2012) rank of tertiary educational institution on webometric (Suhendi, 2012) average GPA score of the new students (Suhendi, 2012) average score of entry examination (Suhendi, 2012) percentage of foreign students' origin (Suhendi, 2012).

The value of customer satisfaction, in this research, is measured using six assessment components,namely reliability, responsiveness, empathy, learning facilities, objectivity guarantee, and supporting facilities. Other indicators used in this research are involvement of alumni and users in UNTAD's activities, ratio of graduates responding to tracking study, percentage growth of the registrant, ratio of registrant compared to prospective graduated students, number of students who participate in a competition, and rank of new students during school.

\subsection{Internal Business Process Perspective}

Some researches measure the performance of internal business process perspective by using academic excellence (Suhendi, 2012; Atafar et al., 2013) quantity and quality of researches and publications (Tohidi et al., 2010; Suhendi, 2012) internship program (Aljardali et al., 2012) existence of special curriculum (Wu et al., 2011; Aljardali et al., 2012) school characteristics (Wu et al., 2011) main programs management (Wu et al., 2011) development of number of faculty/department and study program (Hermawan, 2008; Suhendi, 2012) number of cooperation in research and training (Suhendi, 2012) productivity improvement (Quezada et al., 2014) service achievement through continuous improvement (Aljardali et al., 2012; Santhi et al., 2013) consistency in service provision process (Atafar et al., 2013) service for students (Sukesti, 2010) improvement in team work quality (Nur, 2013) existence of SOP in every service (Wu et al., 2011; Angriani, 2014; Antariksa et al., 2014) and administration effectiveness in tertiary educational institutions (Wu et al., 2011).

This research also measures students quality from non-academic aspect as well as cooperation enhancement. Indicators used to measure students quality from non-academic aspect are percentage of students attending extracurricular, students' entrepreneurship, students' English language skill as well as their soft skill abilities. Indicators used to measure cooperation enhancement are number of cooperation with government agencies, number of cooperation with other tertiary educational institutions, number of foreign cooperation, number of cooperation in alumni recruitment, number of realized $\mathrm{MoU}$, and cooperation partner satisfaction survey.

\subsection{Financial Perspective}

Indicators used by some researchers to measure the performance of financial perspective are strategic investment (Tohidi et al., 2010; Wu et al., 2011; Suhendi, 2012) return on investment (Fooladvand et al., 2015) maintenance of buildings and equipments (Suhendi, 2012) existence of new buildings and equipments which support educational process (Suhendi, 2012) improving profits and investment (Quezada et al., 2014) increasing number of prospective new students (Sudaryo, 2015) revenue improvement (Wu et al., 2011; Effendi, 2012; Suhendi, 2012; Atafar et al., 2013; Christina and Sudana, 2013; Rumintjap, 2013; Angriani, 2014; Fooladvand et al., 2015) availability of financial infrastructure (Atafar et al., 2013) financial report (Hermawan, 2008; Suhendi, 2012) arrangement of budget and financial audit result (Suhendi, 2012) level of efficiency and effectiveness of operational cost (Wu et al., 2011; Suhendi, 2012; Christina and Sudana, 2013; Nur, 2013; Rumintjap, 2013; Angriani, 2014; Antariksa et al., 2014; Quezada et al., 2014; Sudaryo, 2015) and reduction in employee cost (Atafar et al., 2013). Fooladvand et al. (2015) uses the capability of profitability but some researchers measure directly on profitability ratios. The ratios measured are Return on Investment (ROI) (Sukesti, 2010; Wu et al., 2011; Christina and Sudana, 2013) Return on Assets (ROA) (Atafar et al., 2013; Christina and Sudana, 2013) Return on Equity (ROE) (Christina and Sudana, 2013) and profit margin (Sukesti, 2010; Tohidi et al., 2010; Wu et al., 2011). This research uses the percentage of timely financial report and financial audit report by external auditors as performance indicators.

\subsection{Learning and Growth Perspective}

Learning and growth perspective is measured by some previous researchers using staffs capability (Wu et al., 2011; Fooladvand et al., 2015) improvement of manpower quality (Wu et al., 2011; Suhendi, 2012) employees age (Hermawan, 2008) employees' education level (Hermawan, 2008) work experience (Hermawan, 2008) number of education and training (Suhendi, 2012; Christina and Sudana, 2013; Nur, 2013; Rumintjap, 2013; Angriani, 2014) lecturers' education level (Hermawan, 2008) lecturers' rank (Hermawan, 2008) lecturers' teaching experience (Hermawan, 2008) lecturers age (Hermawan, 2008) growth of professional teaching staff (Aljardali et al., 2012) development of working culture (Tohidi et al., 2010) employee turnover (Sukesti, 2010; Wu et al., 2011; Suhendi, 2012; Rumintjap, 2013) employee satisfaction (Hermawan, 2008; Sukesti, 2010; Wu et al., 2011; Suhendi, 2012; Nur, 2013; Angriani, 2014; Antariksa et al., 2014) number of courses which utilize new technology(Suhendi, 2012; Aljardali et al., 2012), capabality of information system (Wu et al., 2011; Suhendi, 2012; Angriani, 2014; Fooladvand et al., 2015). Suhendi (2012) also use the comfort of classrooms, utilization of personnel information system, utilization of financial information system, and attractive website appearance. 
Satisfaction of supporting staff, in this study, is measured in six components, namely suitability of work profession, leadership capability,appreciation or welfare, information systems technology, work atmosphere, and supporting facilities. There are four assessment components to determine the lecturers' satisfaction level, namely competence development, career development, appreciation or welfare, and supporting facilities. This study also adds level of integrated database, IT based and open access library services, and IT management enhancement.

\subsection{Balanced Scorecard by Using Analytic Network Process}

The decision-making process undertaken by management in determining which strategic objectives will become the priority of organization can be done by using analytical tools in order to obtain good and appropriate results. A tool which can be used by researchers in performing weighting or determination of strategy is Analytic Network Process (ANP). ANP is used in the research to determine the weight of each strategic objective in helping organization to improve its performance and achieve its objectives (Wu et al., 2011). ANP is also used due to the presence of feedback relationship between one element and another elements in a component and between elements contained in other components (Suswono et al., 2009; Suhendi, 2012). Moreover, ANP can simplify the complexity of organization, flexibile, and facilitate the determination of strategic priorities (Percin, 2010).

Atafar et al. (2013) reveals that measuring university performance is important in planning a better education. BSC is often used to measure organizational performance. It is considered to better accommodate all needs of organization in performance measurement because it is divided into four perspectives. Integrating BSC and ANP in the study will answer the question regarding relationship of strategic objectives and performance indicators in each interrelated perspective of BSC (Wu et al., 2011; Suhendi, 2012; Atafar et al., 2013; Quezada et al., 2014; Sudaryo, 2015). In line with this statement, Quezada et al. (2014) suggests that the first step in arranging a good strategy map is to classify the strategic goals into four perspectives of BSC and then use ANP to find a causal link between strategic objectives. ANP is employed because it is a good tool for finding a causal relationship and it identifies and estimates whether the effect of relationship between strategic objectives is important or not.

\section{Methods}

\subsection{Research Design}

This research utilizes descriptive technique in the form of case study. It focuses in observing the form of performance measurement used by UNTAD. Respondents are selected using purposive sampling method or also known as judgment sampling (Gay et al., 2012). Respondents, in this study, are parties who are considered able to provide inputs in planning UNTAD's performance measurement. Head of Rector's Advisory Council and five ViceRectors are chosen as respondents because they are the ones in charge and makers of strategic policies while Head of Public Administration Bureau (BAU) and Head of Bureau of Academic Administration, Student Affairs, and Planning (BAKP) are chosen because they are in charge of UNTAD's technical operations. The data collection was conducted on May until August 2016.

\subsection{Operational Definition of Variables}

The operational definition of each BSC perspective analyzed in this research are:

1. Performance of customer perspective is analyzed to identify how the students, alumni, users, and community assess the outputs quality.

2. Performance of internal business process perspective is identify to understand the outputs quality and the efforts made to improve it.

3. Performance of financial perspectives is analyzed to find out whether there is an increase in revenue, strategic investment, and quality of financial administration. Although UNTAD is not a profit-oriented organization, but good financial management must be carried out in an effort to improve the outputs quality.

4. Performance of learning and growth perspective is UNTAD's efforts in improving the quality of resources and develop themselves so that they can respond to customers' needs.

\subsection{Data Analysis}

Data processing and analysis method used in this research are analysis of BSC and ANP BSC does not only describe the financial perspective of organization. BSC could support the management to measure the strength of the organization in achieving customer satisfaction and how business processes as well as invest on resources enhancement to assist the organization in achieving its objectives (Effendi, 2012). BSC principles become the basis in determining strategic objectives and Key Performance Indicators (KPIs) also specify targets and strategic initiatives in achieving strategic objectives. The four perspectives of BSC become the basis for determining priority of strategic objectives.

ANP is a decision-making tool which can find a causal relationship because it identifies whether the effect of the relationship between strategic objectives is important or not based on the weighting (Saaty and Vargas, 2013). ANP is used with the help of Super Decisions software. Super Decisions is a tool useful in decision making by analyzing the level of interest based on dependence and feedback (Linda, 2013). ANP utilization makes it possible to identify which strategic objective that becomes the priority in performance improvement. ANP is applied by developing decision model structure; forming a pairwise comparison matrix of interrelated variables; calculating Consistency Ratio (CR); calculatingsupermatrix; and weighting the importance of component and element. Figure 1 shows the framework of ANP based on BSC. 


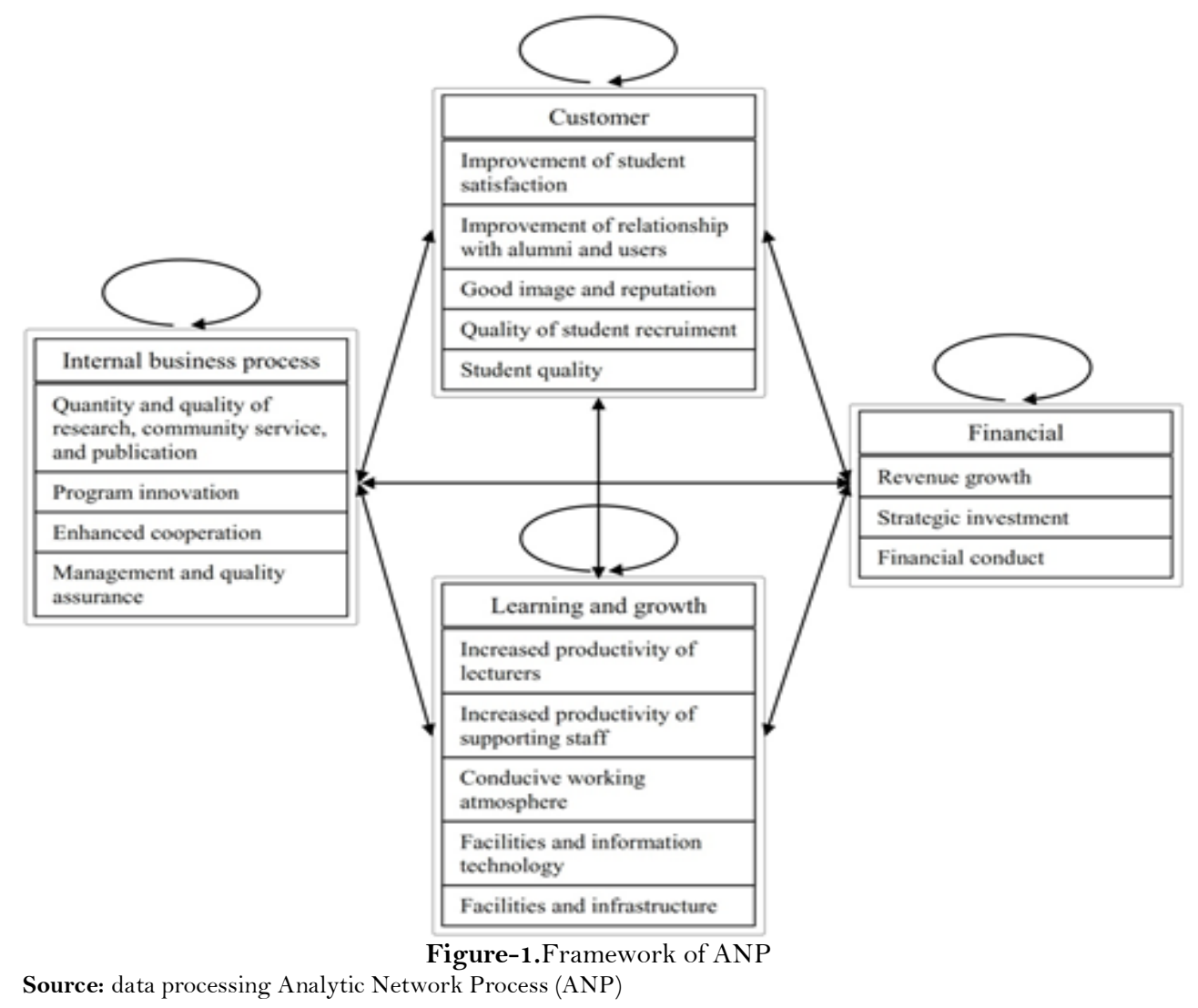

\section{Results and Discussion}

Performance measurement process can be performed using several methods, but the good one is done by determining the right tools in accordance with the purpose of performance measurement and size of the organization (Barnabe and Riccaboni, 2007). BSC which originally was intended for business organizations, has been adopted by many nonprofit organizations as an effort to improve the organizational performance, including adoption by UNTAD. BSC is selected to improve performance because it can be adjusted with the characteristics of each tertiary educational institution (Al-Hosaini and Sofian, 2015). BSC with its four perspectives is expected to be able to answer UNTAD's needs of performance management as well as performance measurement tool.

Customer perspective focuses on UNTAD efforts in satisfying customers. Students, alumni, and users are customersof tertiary educational institutions. UNTAD needs to know organizational performance from customers' eyes in order to continue to improve the service quality with that input. Internal business process perspective focuses on a series of action taken in order to create customer satisfaction. In spite of the limited budget, it would still be able to produce a quality product. Susetyo and Sabakula (2014) reveals that the action taken on internal business process perspective becomes an important process that can attract and retain customers. Financial perspective focuses on effective management and allocation of resources so as to increase customer satisfaction. Finance is one of the important factors for organizations, both profit and non-profit organizations. Good financial management is essential to ensure the organization viability.

UNTAD's status as Public Service Unit (BLU) requires a better fund managemen.UNTAD is not only required to impose transparency, but also to be able to increase revenue despite having limited resources and activity limits from regulation on assets management and revenue of tertiary educational institution. Learning and growth perspective focuses on how to empower UNTAD so as to develop skills in an effort to upgrade customer satisfaction. UNTAD's resources are currently quite limited, therefore it is necessary for UNTAD to do priority mapping so as to know the steps to improve its institutional performance.

BSC development process requires a strong commitment from the leaders so that its implementationcan work well. Effective communication at the time of transformation and investment in information systems will support the success of its implementation (Zin et al., 2013). Leaders as the driver of the organization will determine the success of its implementation. The strategies arranged to improve performance can not work properly if the institution is not ready to implement such strategies (Siswaji, 2013). Leaders should be able to take appropriate measures for the employees' perception of the organization's condition depends on their position within the organization, including the implementation of new policies (Inoshita, 2012). Tohirin (2012) suggests several things to do by the leaders so that the BSC implementation process can be carried out well, namely increasing the awareness of officials and staffs that bureaucratic reform happens, providing socialization of BSC concept, conducting aanalysis of the need of employee training, upgrading employee competence, preparing job competence standards, improving IT management, arranging guidebook of performance measurement, and forming a BSC team.

Good strategic objectives for the organization arestrategic objectives arranged based on vision, mission, and goals of the organization. The process of planning and setting strategic objectives, KPIs, targets, and strategic initiatives into measures to enable the achievement of institution's goals. The number of strategic objectives on UNTAD's four BSC perspectives is 17 with 75 KPIs. Each KPI has a target and strategic initiative. KPIs, targets, and strategic initiatives are organized based on UNTAD's strategic plan 2015-2020, elements of BAN-PT's institutional accreditation assessment and in-depth discussions with the working units' party. KPI is a tool to measure the strategic objectives. Targets are set as performance standardof certain periods while strategic initiatives are activities undertaken in an effort to achieve the targets. 
The strategic objectives are components which if it is executed well, it can improve organizational performance. Each strategic objective has a different contribution for performance improvement. Results of strategic objective weighting using ANP generate priorityweight that describes how large the strategic objective will support the organization in achieving its expected performance. The greater the weight, the greater the contribution of strategic objective in performance improvement, so that the strategic objective should be a priority. Contributions of strategic objectives for each perspective can be seen in Figure 2.

UNTAD's BSC is developed based on four perspectives of BSC. Customer perspective contributes the most to UNTAD's performance improvement with the value of 0.300. Perspective which ranks the second is learning and growth perspective with the value of 0.285 . It is followed by internal business process perspective with the value of 0.212 . The last one is financial perspective with the value of 0.203 . The results of this calculation indicate that customer perspective is the first perspective that should be prioritized in order to achieve the performance improvement. Contribution of each perspective is the accumulation of strategic objectives' contribution which exists in each perspective.

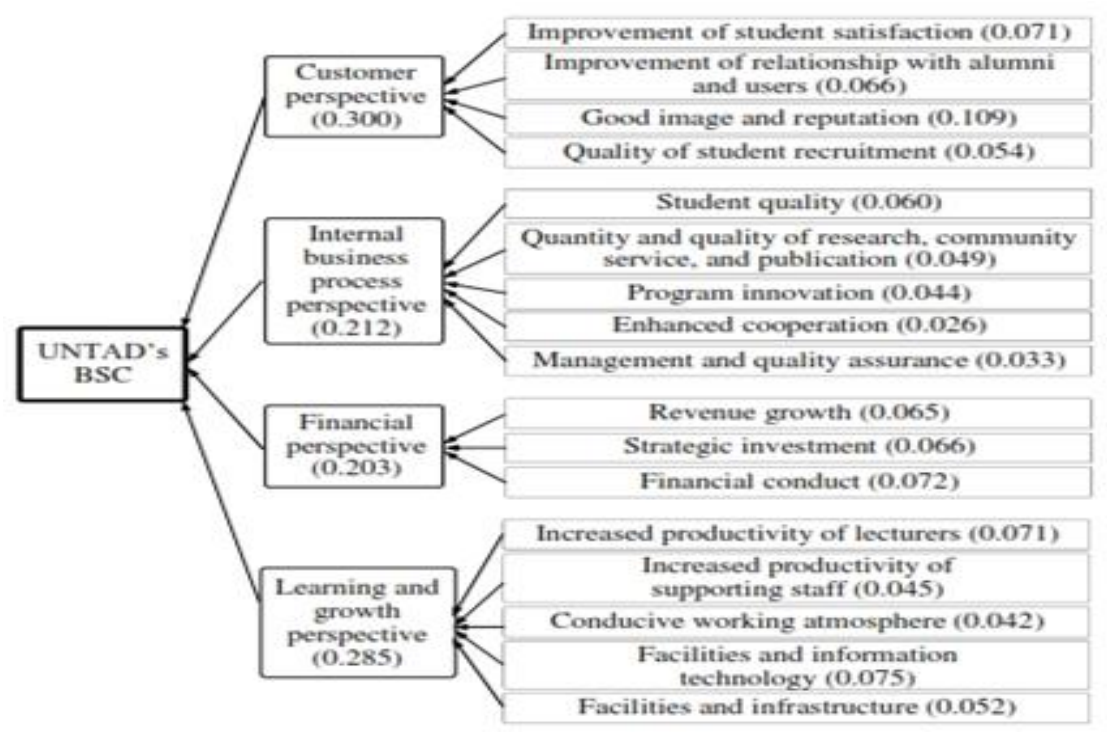

Figure-2. Contribution of strategic objectives on each BSC perspective Source: data processing Balanced Scorecard

Placement of customer perspective as the first priority is in line with research conducted by Suhendi (2012) but in that study, internal business process perspective ranks the second, growth and learning perspective ranks the third, and financial perspective is the last one. Slightly different from the research conducted by Sudaryo (2015) in that study, internal business process perspective is the first priority, followed by customer, learning and growth, and financial perspective. In line with the research of Wau (2008) which reveals that tertiary educational institution positions its student as the center of activity, both direct and indirect lessons conducted for the students. Lecturer competence improvement through research, community service, continued study, as well as workshops and seminars are also organized in an effort to improve services for students. In contrast with the reasearch of Sudaryo (2015) and Suhendi (2012) as well as this research, the research conducted by Riza (2015) show that financial perspective is not in the last position but in the second position following internal business process perspective. Priority weight for each perspective is portrayed in Figure 3.

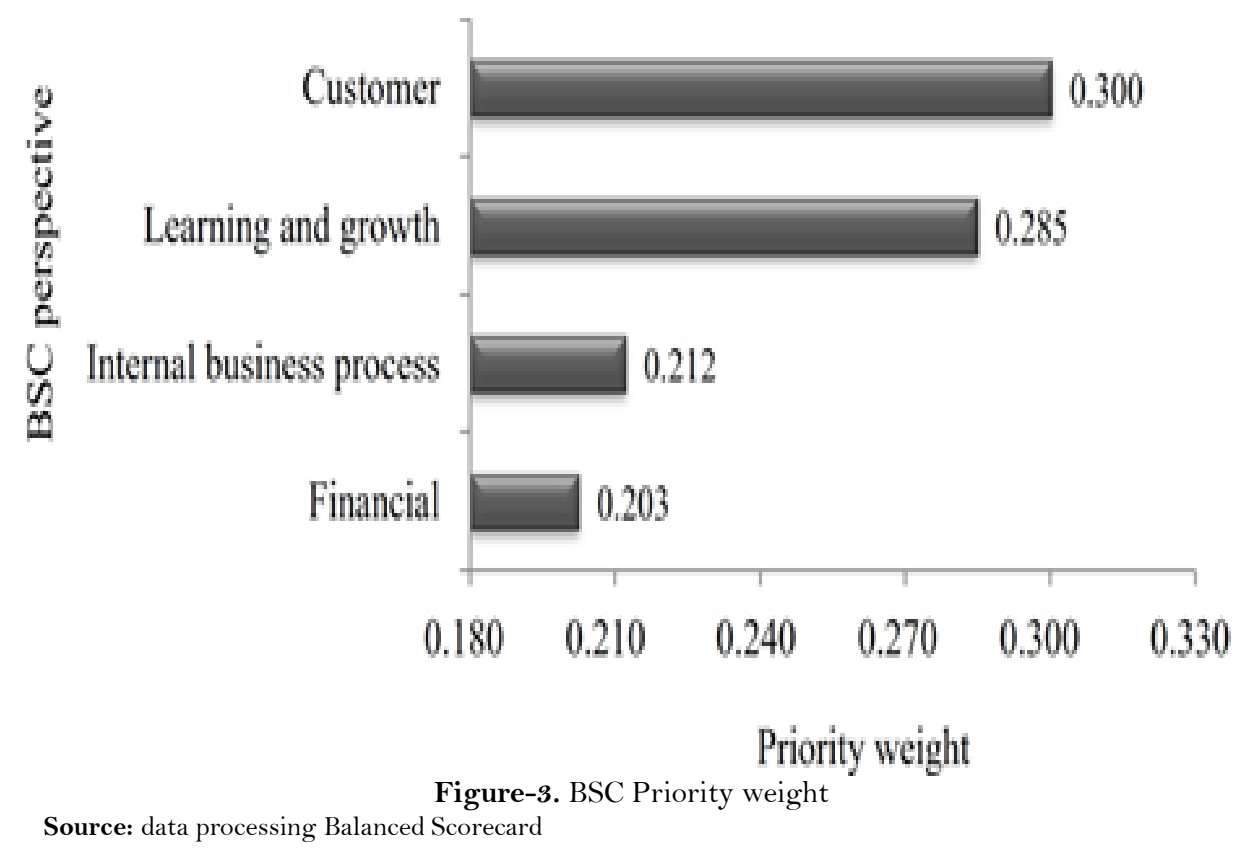

Based on the result of weighting priority on customer perspective, good image and reputation becomes the strategic objective at first priority. It is followed by improvement of student satisfaction, improvement of relationship with alumni and users, and quality of student recruitment. A good image and reputation is indispensable for tertiary educational institution to carry out its activities. Enhancement in number of students and cooperation with other parties in various types of activity can organized if the institution owns a good name. Based 
on the result of priority weighting on internal business process perspective, the strategic objective of student quality holds the first priority. Quantity and quality of research, community service, and publication, program innovation, mmanagement and quality assurance, and eenhanced cooperation follow the first priority sequentially. Student quality improvement can be undertaken with the presence of continuous and consistent quality assurance (Khoiri, 2009). Based on the result of priority weighting on financial perspective, financial conduct is the strategic objective which should be prioritized first. Strategic investments and revenue improvement come later sequentially. Financial administration which is arranged properly and according to the rules is one of the keys in conducting financial conduct. Based on the result of weighting priority on learning and growth perspective, ffacilities and information technology becomes the main strategic objective. Following the main strategic objective are increased productivity of lecturers, adequate facility and infrastructure, iincreased productivity of supporting staffproductivity improvement, and conducive working atmosphere. A highly rapid information technology development encourages tertiary educational institution to engage in order to compete well. A good information technology development will greatly help the institution in performing its very complex activity.

\section{Conclusion}

The number of strategic objectives which are arranged based on UNTAD's BSC is 17 with 75 KPIs. The determination of strategic objectives and initiatives is carried out according to UNTAD's Strategic Plan 20152020, BAN-PT standard, and in-depth discussions with the working units' party. Prioritization of strategic objectives is done using ANP method and processed using Super Decision software version 2.0.8. The results of this study indicate that customer perspective holds the first priority with the value of 0.300 ,followed by learning and growth perspective with the value of 0.285 , internal business process perspective with the value of 0.212 , and financial perspective with the value of 0.203 .

In this study, weighting was only analyze based on the strategic objectives, it is suggested for further research to analyze the weighting of KPI so the measurement will getting better and proportionate. Other measurement tools such as Baldrige Excellence Framework (BEF) on performance measurementcan be used for other universities such as Hasanuddin University, Bogor Agricultural University (IPB), University of Gadjah Mada (UGM), etc, which have more complex performances.

\section{Recommendations}

BSC utilization for performance improvement is good to be applied in UNTAD because it does not only develop strategic objectives, but also provide feedback in the form of a scorecard. UNTAD's BSC development can be planned in BAKP, implemented by all units, and evaluated by UNTAD's internal auditor (SPI).

The strategic goal which becomes first priority on customer perspective is good image and reputation. The supporting factors of this strategic objective are percentage growth of the registrant, ratio of registrant compared to prospective graduated students, and number of students who participate in a competition. Student quality is a top priority of internal business process perspective.

Student quality can be achieved through percentage of graduates with GPA $\geq 3.25$,percentage of on-time graduates, percentage of dropped out of college, average study period, number of latest text books per year, Higher education-accredited journals and electronic journals subscribed, percentage of learning with Student-centered Learning (SCL), reconstruction of competence-based curriculum, percentage of students participating in extracurricular and leadership, strengthening of student institutional function, students' entrepreneurship, students'English skill, and students' soft skill abilities.

Financial conduct is strategic objective which becomes a top priority on financial perspective. Financial conduct can be achieved through timely arrangement of financial statement and financial audit report by external auditors.

Priority strategic objective in learning and growth perspective is facilities and information technology. Efforts which support the achievement of this strategic objective are development of academic information systems, establishment of integrated database, attractive website appearance, IT quality which is adequate for learning and teaching process, IT-based and open access library services,and IT management improvement.

\section{References}

Al-Hosaini, F.F. and S. Sofian, 2015. A review of balanced scorecard framework in higher education institution (HEIs). International Review of Management and Marketing, 5(1): 26-35. View at Google Scholar

Aljardali, H., M. Kaderi and T.L. Tadjine, 2012. The implementation of the balanced scorecard in Lebanese public higher education institutions. Procedia- Social and Behavioral Sciences, 62: 98-108. View at Google Scholar $\mid$ View at Publisher

Angriani, F.A., 2014. The design of balanced scorecard based performance measurement at Sekupang Ferry terminal. [Master Thesis $\rceil$. Bogor: Bogor Agricultural University.

Antariksa, W.F., Surachman and M. Setiawan, 2014. Influence of implementation of quality management system of Iso 9001 : 2008 in university toward balanced scorecard performance (Case Study In UB). Journal of Application Management, 12(3): 399-406.

Atafar, A., M.A. Shahrabi and M.J. Esfahani, 2013. Evaluation of university performance using BSC and ANP. Decision Science Letters, 2(4): 305-31 1. View at Google Scholar | View at Publisher

Barnabe, F. and A. Riccaboni, 2007. Which role for performance measurement systems in higher education? Focus on quality assurance in Italy. Studies in Educational Evaluation, 33(3-4): 302-319. View at Google Scholar | View at Publisher

Christina, N.P.Y. and I.P. Sudana, 2013. Performance appraisal at PT. Adhi works with Balanced Scorecard approach. E-Journal of Accounting Udayana University, 5(3): 516-529.

Dessler, G., 2006. Human resource management. Rahayu P, translator; Hardiansjah FH, Editor. Jakarta: Index, ke-1.

Effendi, R., 2012. Measurement of public sector performance by using Balanced Scorecard (Case Study of DGT Regional Office of South Sumatra and Kep Babel). Scientific Journals STIE MDP, 1(2): 67-73.

Fitriyani, D., 2014. Balanced scorecard: An alternative measure of the performance of public sector organizations. Journal of the Accounting Horizon, 6(1): 16-31.

Fontanella, A. and W. Andriani, 2009. Analysis of performance measurement of state universities in west Sumatera with balanced scorecard approach perspective of internal business process and growth and learning. Journal of Accounting \& Management, 4(1): 75-83.

Fooladvand, M., M.H. Yarmohammadian and S. Shahtalebi, 2015. The application strategic planning and balance scorecard modelling in enhance of higher education. Procedia-Social and Behavioral Sciences, 186: 950-954. View at Google Scholar $\mid$ View at Publisher

Gay, L.R., G.E. Millis and P.W. Airasian, 2012. Educational research: Competencies for analysis and applications. 10th Edn.: US. Pearson Education, Inc. 
Hermawan, S., 2008. Implementation of balance scorecard as a tool of strategy implementation in an effort to improve the performance of Muhammadiyah University of Sidoarjo. Journal of Business Economics and Accounting VENTURA, 11(2): 1-18.

Inoshita, L.T., 2012. Quality of worklife and higher education support personnel: Testing the generalizability of a proposed model. Doctoral Dissertation. Manoa (US): University of Hawai'i.

Kaplan, R.S. and D.P. Norton, 1996. Translating strategy into action. Boston, MA: Harvard Business School Press.

Khoiri, M., 2009. Efforts to improve the quality of college graduates to meet the needs of industrial human resources with the TQME approach. National Seminar V HR Nuclear Technology; 2009 Nov 5; Yogyakarta, Indonesia. Yogyakarta. pp: 37-45.

Law Number, 2012. About higher education.

Linda, D., 2013. The use of super-decision software in determining lecturer faculty in private universities. Journal of Informatics, 13(1): 2332.

Niven, P.R., 2008. Balanced scorecard step-by-step for government and nonprofit agencies. 2nd Edn., New Jersey: John Wiley \& Sons, Inc.

Nur, R.R., 2013. Performance measurement of industry, trade, cooperative and SME Office of Mukomuko Regency, Bengkulu. [Master Thesis]. Bogor : Bogor Agricultural University.

Percin, S., 2010. Use of analytic network process in selecting knowledge management strategies. Management Research Review, 33(5): 452471. View at Google Scholar | View at Publisher

Quezada, L.E., P.I. Palominos, R.E. Galleguillos and A.H. Olmedo, 2014. A method for generating strategy maps using ANP. Journal of Manufacturing Technology Management, 25(8): 1090-1 104. View at Google Scholar | View at Publisher

Riza, B.S., 2015. Company performance measurement using analytic network process (Case Study at PT Telemedia Network Cakrawala). Exploratory Informatics, 5(1): 51-62.

Rumintjap, M.L., 2013. Implementation of balanced scorecard as a benchmark of performance measurement in RSUD Noongan. Journal of EMBA, 1(3): 841-850.

Saaty, T.L. and L.G. Vargas, 2013. Decision making with the analytic network process: Economic, political, social and technological applications with benefits, opportunities, costs and risks. 2nd Edn., New York: Springer.

Santhi, M.W., M. Rahayu and Noermijati, 2013. Application of strategic management with Balanced Scorecard approach (study at Quality Assurance Institute of Education of Bali Province). Journal of Application Management, 1 1(4): 648-656.

Siswaji, 2013. The influence of institutions and strategies on the performance of state-owned enterprises (SOEs). [Doctoral Dissertation]. Bogor: Bogor Agricultural University.

Sudaryo, Y., 2015. Performance of universities with a strategic map balanced scorecard approach: Study at 6 high school of economics in Bandung city. Sosiohumaniora, 17(1): 1-12.

Sudirman, I., 2012. Implementing balanced scorecard in higher education management. International Journal of Business and Social Science, 3(18): 199-200. View at Google Scholar

Suhendi, 2012. Design of MB-IPB performance measurement system with balanced scorecard method. [Master Thesis]. Bogor: Bogor Agricultural University.

Sukesti, F., 2010. Analysis of the use of balanced scorecard as an alternative to measure performance at the University of Muhammadiyah Semarang. Proceedings of the National Seminar of UNIMUS 2010; 2010 January 12; Semarang, Indonesia. Semarang. pp: 416-424.

Susetyo, J. and A.U.L. Sabakula, 2014. Performance measurement using balanced scorecard and Integrated performance measurement system (IPMS). Journal of Technology, 7(1): 56-63.

Suswono, D.A., M.H. Sawit and B. Arifin, 2009. Strategies to increase the competitiveness of bulog. Journal of Management \& A gribusiness, 6(2): 91-108.

Tohidi, H., A. Jafari and A.A. Afshar, 2010. Using balanced scorecard in educational organizations. Procedia Social and Behavioral Sciences, 2(2): 5544-5548. View at Google Scholar $\mid$ View at Publisher

Tohirin, 2012. The design of performance measurement with balanced scorecard approach on Pusdiklat Tenaga administrasi R \& D agency and ministry of Religious Affairs. [Master Thesis]. Bogor: Bogor Agricultural University.

Wau, Y., 2008. Efforts to optimize the performance of educative personnel in universities. Journal Tabularasa PPs Unimed, 5(1): 55-72.

Wibisono, E., L. Mardiono and P.S. Wijaya, 2011. Integration of analytics model and performance dashboard in performance measurement using balanced scorecard. Proceedings of the 6th National Industrial Engineering Conference; 2011 Oct 20; Surabaya, Indonesia. Surabaya: NIEC6. pp: 76-83.

Wu, H.Y., Y.K. Lin and C.H. Chang, 2011. Performance evaluation of extension education centers in universities based on the balanced scorecard. Evaluation and Program Planning, 34(1): 37-50. View at Google Scholar | View at Publisher

Zin, N.M., S. Sulaiman, A. Ramli and A. Nawawi, 2013. Performance measurement and balanced scorecard implementation: Case evidence of a government-linked company. Procedia Economics and Finance, 7: 197-204. View at Google Scholar | View at Publisher

\section{Bibliography}

BAN-PT National Accreditation Board of Higher Education, 2016. Directory of SK result of accreditation of study program. Available from http://ban-pt.kemdiknas.go.id/direktori.php [Accessed 17February 2016].

Decree of Government of Republic Indonesia No.12 Year 2012 regarding high education. Jakarta: State Secretary.

Untad Tadulako University, 2014. Tadulako university strategic plan 2015-2020. Hammer: Untad. 